\title{
THE OBESITY PREVALENCE IN NAVY PERSONAL AND CIVIL SERVANTS AT LANTAMAL X JAYAPURA
}

\author{
Yuli Arisanti'), Janri Manullang2) \\ 1)National Institute of Health Research and Development Papua \\ ${ }^{2)}$ Navy Central Hospital Dr. Soedibjo Sardadi
}

\begin{abstract}
Background: Central (visceral) obesity, one of the risk factors of metabolic syndrome, is becoming the major public health concern of non-communicable diseases. Predictions estimated that by 2030, 50\% of adults will be listed as obese. This study aimed to examine smoking and exercise as the risk factors of central obesity in navy personal and civil servants at Lantamal X Jayapura.

Subjects and Method: This was a cross sectional study conducted from November to December 2017 at Lantamal X Jayapura, Indonesia. A sample of 100 navy personal and civil servants was selected by random sampling. The dependent variable was central obesity. The independent variables were smoking and exercise. Waist circumference was measured by metline. The other variables were collected by questionnaires. Data were analyzed by Chi square.

Results: The risk of central obesity increased with smoking $(\mathrm{OR}=3.13 ; 95 \% \mathrm{CI}=1.63$ to 5.98; $\mathrm{p}<0.001)$ and duration of exercise less than 60 minute per week $(\mathrm{OR}=2.49 ; 95 \% \mathrm{CI}=$ 1.14 to $5.40 ; \mathrm{p}=0.017$ ).

Conclusion: Risk of central obesity increases with smoking and duration of exercise.
\end{abstract}

Keywords: central obesity, smoking, exercise, navy personal, civil servants

Correspondence:

Yuli Arisanti. National Institute of Health Research and Development Papua. Jl. Ahmad Yani No. 48, Gurabesi, Jayapura Utara. Email: yuliarisanti88@gmail.com. Mobile: +6281248978639 .

The $7^{\text {th }}$ International Conference on Public Health

Solo, Indonesia, November 18-19, 2020 | 74

https://doi.org/10.26911/the7thicph.01.29 